\title{
The development of Virtual Javanese Gamelan to improve Gamelan learning achievement
}

\author{
Mohammad Safari \& Dennis Ossy January \\ MI Miftahul Huda 01 \\ SD Plus Muhammadiyah Boyolali \\ mohammad.safari9@gmail.com \\ DOI: $10.18326 /$ mudarrisa.v10i2.222-244
}

\begin{abstract}
This study aims to develop innovative, effective and practical learning media to improve learning achievement of students in memorizing and recognizing the basic instruments of gamelan. The background of this study is that there are still many elementary school (SD) and Islamic elementary school (MI) students who do not know the basic instruments of gamelan, which hinder the achievement of Javanese language competencies. This method of developing learning media uses research and development method steps. Dissemination is carried out at the Central Java Center of Education Information and Communication Technology Development (BPTIKP) for the implementation toward more targeted users. The results of the study show that they have succeeded in developing the Virtual Virtual Javanese Gamelan in which the students can use to play while learning. The learning results show a significant increase in learning achievement, in the initial conditions without using Virtual Javanese Gamelan, from 18 students, only 5 students (27.8\%) have completed the learning with an average score of 66 . While the learning results obtained after using the Mutimedia Virtual Javanese Gamelan, the completion reaches 18 students (100\%) with an average score of 90 . So it can be concluded that Virtual Javanese Gamelan multimedia can improve the learning achievement of the second graders at MI Miftahul Huda 01.
\end{abstract}

Keywords: Virtual Javanese Gamelan, Lectora Inspire, gamelan 


\section{INTRODUCTION}

Javanese Language subjects, especially in Central Java, is one of the mandatory local content subjects that must exist at every level of school, both basic and secondary education, this is stated in the circular letter of the Central Java Education Office No. 433.5 /14995 dated 04 June 2014 concerning the implementation of the 2013 Curriculum in Javanese Language Subjects. The decree also contains a number of core and basic competencies that must be achieved by each student in participating in the teaching and learning process of Javanese language local content subjects, one of which is basic competency in knowing the name of the gamelan instrument.

Basic competency in recognizing the name of the gamelan instrument is the basic competency for the basic education level especially for the second graders of SD/MI at the first semester. The achievement indicators are not easily gained because the fact that MI Miftahul Huda 01 Semarang Regency shows the low activity of students in learning local Javanese content, resulting in low learning achievement obtained by students. In general, students are less enthusiastic in following the teaching and learning process. This is proven by the small number of students who show their interest in knowing gamelan.

The local content of Javanese Language especially the material of recognizing the name of the gamelan instrument is felt to be less attractive to students, this can be seen from the lack of motivation and curiosity of students to understand problems related to gamelan 
instruments, so that the majority of students experience proven learning difficulties from learning Javanese subjects in MI Miftahul Huda 01 material "Getting to know pandawa and punakawan figures" is very low, that can be seen from the daily test $(\mathrm{UH})$ results that do not comply with the minimum criteria of mastery learning (KKM) which have been determined as 70. The student's daily test scores are shown in Table 1 .

Table 1 . The analysis of daily test results

\begin{tabular}{cccc}
\hline Scores & Number of Students & Percentage & Completion \\
\hline $71-80$ & 5 & $27,8 \%$ & Pass \\
$61-70$ & 9 & $50,0 \%$ & Fail \\
$<60$ & 4 & $22,2 \%$ & Fail \\
\hline Total & 18 & $100 \%$ & \\
\hline
\end{tabular}

Identifying learning difficulties is very important for teachers because the teacher's task is not only to convey the materials to students but more than that, the teacher is obliged to create a pleasant learning atmosphere, attract students to always learn, develop team works, be creative and innovative. In fact, Javanese language learning is still considered a boring lesson and it has many obstacles on several sides, there are at least 4 (four) obstacles that the authors have identified.

The internal obstacle of the school is the limitations on the number of gamelan owned. The study of gamelan musical instruments should be using the learning media in the form of the gamelan instruments so that students can learn to recognize the names of gamelan instruments, practice to beat gamelan and play gamelan instruments so that they will provide a real experience while providing meaningful learning to students. As we all know, the price of a gamelan musical 
instrument can reach millions or even tens of millions of rupiah, so not all schools can provide it for gamelan learning media.

The second obstacle is the paradigm of gamelan instruments. Gamelan instruments are often viewed with one eye as an ancient musical instrument, outdated and less contemporary. Students are more interested in modern musical instruments such as drums, guitars, basses and pianos which they consider to be slang, in time and present. The oldfashioned view also occurs in other Javanese language material such as the material "knowing the characters of Pandawa and the Poets". Students are more familiar with loving outside figures such as Spongebob, Bobo Boy, Dora, Ipin Upin than knowing figures who uphold local wisdom such as Pandawa Lima. This view will cause a fatal impact if it is not immediately addressed, namely the absence of feelings of belonging and culture and local wisdom which results in the loss of Javanese identity and character that is polite, gentle, both on words and actions, namely "wong jawa ilang jawane" (Javanese people who do not know about Javanese custom and culture).

The third obstacle is from the teacher, among them are the teachers who have not mastered the gamelan instruments themselves because they do not have a Javanese language education background, even though the law of teachers and lecturers suggest teaching and educating in accordance with their competence and professionalism. The fourth obstacle is the lack of hours of face-to-face subjects in Javanese language. The local content curriculum of Javanese only provides $1 \mathrm{x}$ 


\section{Mudarrisa: Jurnal Kajian Pendidikan Islam, Vol. 10, No. 2, 2018}

hours of face-to-face in a week, with a duration of $2 \times 35$ minutes even though the material to be achieved is very heavy as well as Indonesian language subjects which are given 3 hours of face a week.

Another obstacle identified by the author is that the material in the textbook is very limited in its explanation. There are only 2 pages that describe the gamelan instruments, 1 page for the material and the next page for assignments. This is not comparable with the learning indicators to be achieved because the material distribution and depth of material explanation recognize the names of very shallow gamelan instruments.

To overcome the problems and obstacles listed above, the authors try to innovate by making and utilizing interactive learning media on gamelan learning using the Lectora Inspire software. Furthermore, the author develops an innovative and interactive learning media called Virtual Javanese Gamelan, which is an interactive learning media gamelan that is packaged in digital form so students can play gamelan instruments in real and real terms like playing gamelan instruments in real life. This Virtual Javanese Gamelan interactive learning media is then briefly called VJG. This VJG interactive learning media is expected to increase learning motivation, and foster students' curiosity towards the gamelan material so that the activities and learning achievement of recognizing gamelan instruments get a significant increase. 


\section{METHODS}

The type of this research is research and development $(R \& D)$ which is a research method used to produce certain products, and test the effectiveness of these products. The development model used is a procedural model adapted from the instructional design development model according to Dick \& Carey and the development research model according to Borg \& Gall, with certain stages of development.

Identification Stage

The identification phase includes: (a) Identification on field needs; (b) Identification of objectives, characteristics of students, facilities and infrastructure; (c) Identification of the curriculum, to determine teaching materials.

Design and Development Phase

This phase of activity is to design and develop programs in the form of design documents according to the steps adapted from the Dick \& Carey model, including the preparation of flow charts, research scripts, and storyboards. The steps of this stage are 1) Formulation of core competencies; 2) Analysis of core competencies; 3) Identification of students' initial abilities and characteristics; 4) Formulating learning competencies; 5) Choosing learning strategies and learning experiences; 6) Translation of basic competencies into indicators; 7) Development of test items based on benchmark reference. 


\section{Production Stage}

Activities at this stage are making or assembling media objects, such as making images clip art, animation and video.

Evaluation Phase

The evaluation phase is carried out with validation and trial steps including: 1) validation of material experts and learning media experts; 2) individual trials; 3) small group trials; 4) large group trials and 5) application in learning.

\section{RESULTS AND DISCUSSIONS}

Virtual Javanese Gamelan (VJG) is a form of interactive learning media created by the authors using the Lectora Inspire software. Dealing with interactive learning media, Asyhar $(2011,75)$ explains that media is a unity between various media (file format) in the form of text, images, graphics, sound, animation, video, interactions that have been packaged in digital files (computerized), used to convey messages to the public. Agreeing with him, Sukiman $(2012,29)$ states that learning media is everything that can be used to channel messages from senders to recipients so as to stimulate students' thoughts, feelings, concerns and interests in such a way that the learning process occurs in order to achieve effective learning goals. Media is said to be a medium of learning if the media carries messages or information aimed at instructional or contains the purpose of teaching (Arsyad, 2011:4). 
The word 'interactive' according to the online Large Indonesian Language Dictionary (KBBI) (http://kbbi.web.id/interaktif, accessed on October 11, 2015) means having the nature of mutual action, interrelations, mutual cooperation. Whereas in the learning media the word 'interesting' is often interpreted with media that provides a relationship of feedback between users (in this case students) with the media. So, interactive media is learning media which is a combination of various media (file formats) in the form of text, images, graphics, sound, animation, videos, interactions, etc, which has been packaged into a digital file (computerized), used to convey messages to students and provide a relationship of feedback or feedback.

Benefits and Functions of Learning Media

Sukiman $(2012,41)$ states that the use of media in learning can arouse new desires and interests, increase motivation and stimulation of learning activities, and even new interests in students. The function of learning media is related to the problems of the learning process in the classroom, namely: 1) Clarify the presentation of the message so it is not too verbal, 2) Overcoming limitations of space, time, and memory, 3) The use of educational media appropriately and variations can overcome the passivity of students, 4) Giving the same stimulation, 5) Learning media provide direct interaction.

Learning achievement

Sudjana $(2007,3)$ defines learning achievement as behavioral changes that cover the cognitive, affective, and psychomotor fields that students 


\section{Mudarrisa: Jurnal Kajian Pendidikan Islam, Vol. 10, No. 2, 2018}

have after receiving their learning. Among the three domains, the cognitive domain is one of the most likely aspects to serve as a benchmark for achieving learning achievement, because the cognitive domain (cognitive domain) is an area of learning achievement related to the level of understanding related to the structure of the material obtained from the learning process.

Bloom in Sudjana $(2007,7)$ in detail explains that the scope of learning achievement in the cognitive domain includes six criteria. Among them; (1) Knowledge is the ability to remember about something that has been studied and stored in memory (memory). Understanding is the ability to understand or explore the meaning of the material that has been studied. (3) Application is the ability to apply material that has been studied and mastered. (4) Analysis, namely the ability to understand the relationships between material components, so that they can be understood as material conclusions. (5) Synthesis is the ability to integrate concepts or material structures so as to create new understanding. (6) Evaluation is the ability to give consideration to material values for specific purposes. The six aspects in the cognitive domain above can be achieved if several factors of influence can be positively supported in the learning process. Whereas according to Baharuddin $(2007,16)$ student learning achievement is influenced by the learning process, the learning process is a series of activities that occur at the nerve center of the learning individual. The learning process takes place abstractly, because it occurs mentally and cannot be observed. The 
learning process can only be observed if there is a change in behavior from someone who is different from before. Changes in behavior are common in terms of knowledge, affective and psychomotor.

Javanese Language Subjects

Based on a letter from the Central Java Provincial Education Office Number 424/13242 dated July 23, 2013 regarding the implementation of Javanese language local content in the 2013 curculum in Central Java, one of mentioned things is that Javanese is a mandatory local content in Central Java which is separate or independent as a subject. The allocation of Javanese language local content hours is 2 (two) hours per week allocated to the 2013 curriculum structure. One of the Javanese language competency standards in grade 2 elementary schools is "Getting to know gamelan music instruments". Based on the curriculum mandate, students are expected to be able to identify the names of gamelan, imitate the sound of the gamelan and describe the names of gamelan instruments both verbally and in writing.

Ferdiansyah $(2010,23)$ states that gamelan is a set of musical instruments with pentatonic tones, which consist of: Kendang, Bonang Barung, Bonang Penerus, Demung, Saron Barung, Saron Panerus, Peking (Gamelan), Kenong and Kethuk, Kempyang, Slenthem, and Gong. The word gamelan itself comes from the Javanese language 'gamel' which means hitting/beating, followed by the suffix '-an' which makes it a noun. While the term gamelan means as a single musical instrument played together. 


\section{Discovery (Renewal) Process}

On this occasion the author designed Virtual Javanese Gamelan learning media which the author gave the title "Fun Playing Gamelan" which the authors hoped would be useful to help students understand students in knowing the types of gamelan instruments in a fun way. Why is it given the name "Fun Playing Gamelan"? Nothing else is to give a tempting first impression, that with a word "fun" fosters enthusiasm and gives a pleasant impression of learning. The steps taken in making the Virtual Javanese Gamelan media are as follows: Making a script

Animation is made as an arrangement of storylines, for which ideas and a story are needed so that learning can be delivered in a fun way, see Figure 1.

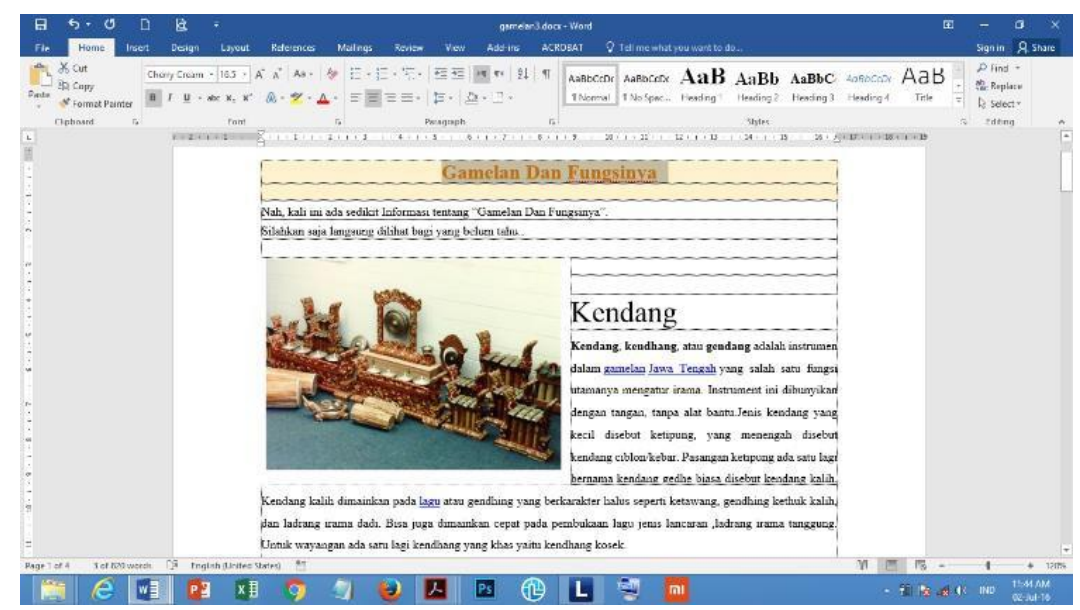

Figure 1. Material Text and storyboard 
Creating visual characters and materials

Creating visual characters and materials in making media using Photoshop CS 6 software, see Figure 2.

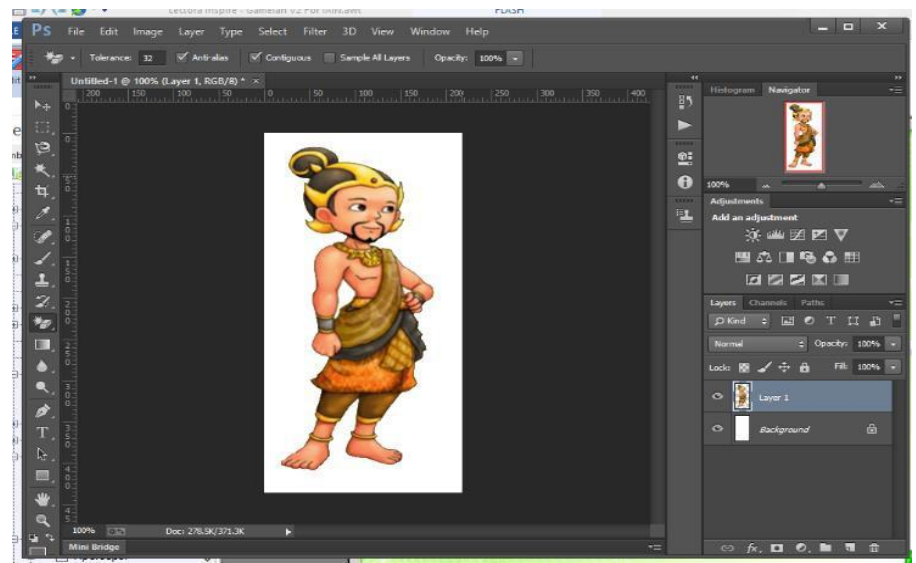

Figure 2. Making the Janaka Character in Photoshop

Making the initial template in the Lectora Inspire software

Making the initial template by providing navigation buttons and explanations in the use of media need to be prepared in making the media are navigation icons (home, material, evaluation, games, Competence Standard/Basic Competence, profile and exit), see Figure 3.

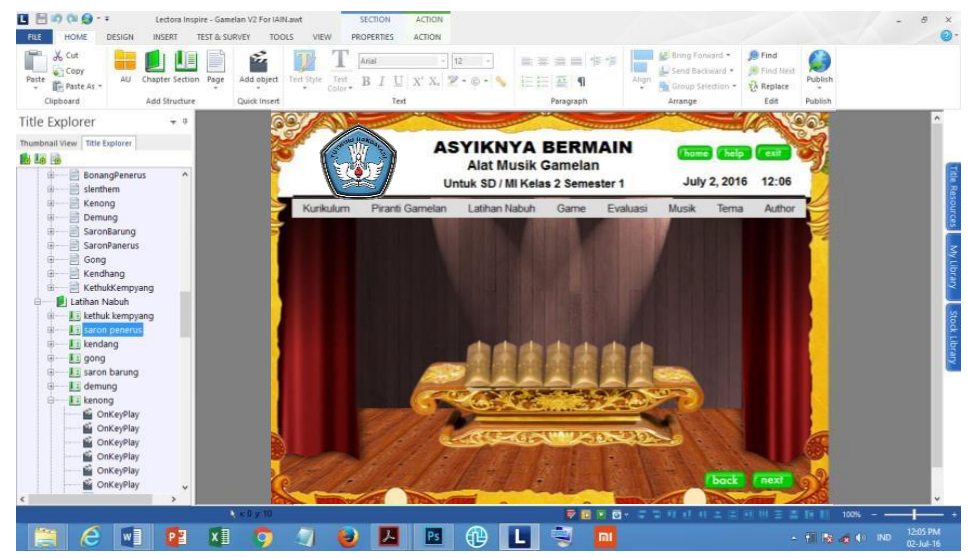

Figure 3. Making Beat Templates in Virtual Javanese Gamelan 
Entering material into the template

Presentation of material is in the template by using the principles stated by Ricard E Mayer (2001: 15), so that the material presentation is easily understood by students. Virtual Media Javanese of this gamelan optimizes the principle of redundancy, namely the combination of animation and narration, see figure 4 .

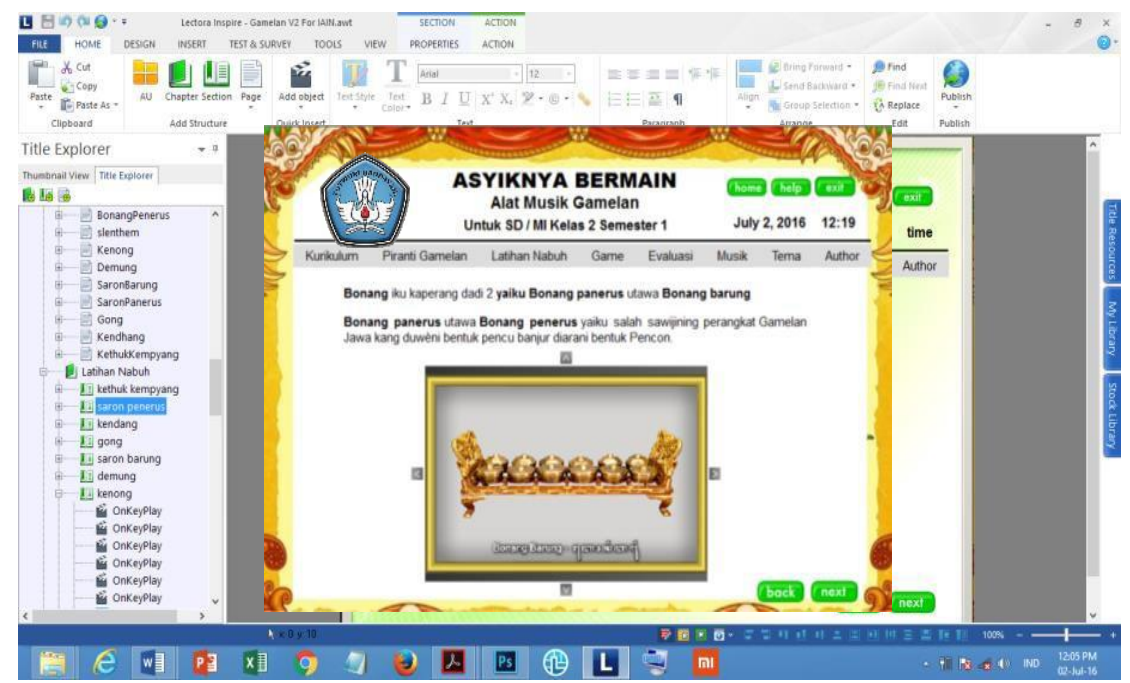

Figure 4. Presenting material on Virtual Javanese Gamelan

Language of programming (coding)

The next step is providing a language of programming (coding) to optimize the media functions of Virtual Javanese Gamelan. Additional action scripts include dropdown menus, plant training, games, evaluation and print charter, see figure 5 . 


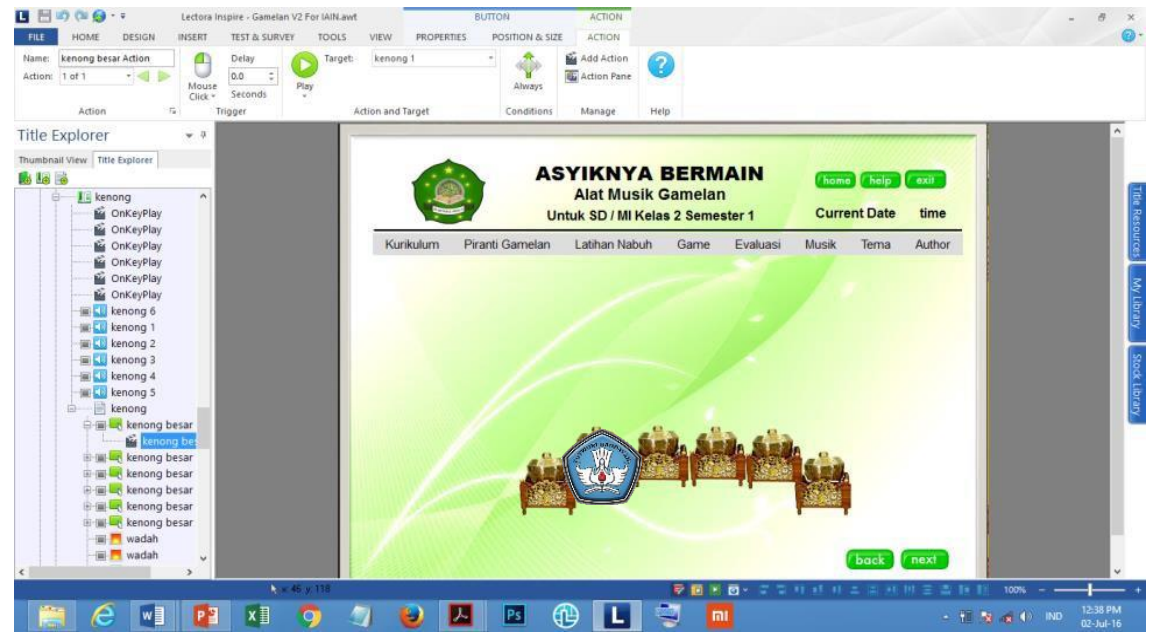

Figure 5. Coding on Virtual Javanese Gamelan

Testing and making improvements

Testing and making improvements ensure the use of Virtual Javanese Gamelan media can be used in learning by paying attention to navigation, visuals, and the material has been presented in accordance with the plan, see figure 6 .

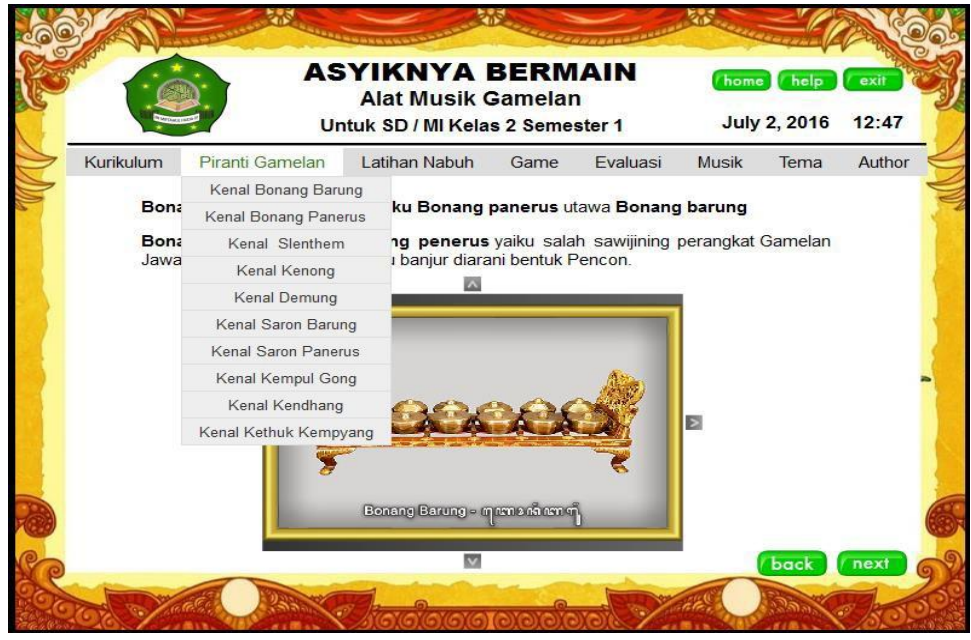

Figure 6. Testing product feasibility before use in learning 
Conducting a series of discussions

On September 20, 2015 the authors validated the team consisting of 10 validators (see Figure 7). The results of the validation from the aspect of effectiveness and practicality of the media are very good but there are some suggestions that the authors receive relating to the voice of the narrative and the time limit in working on evaluation questions. On the next step, the authors revise the voice of the narrative which is originally the voice of an adult changed to the sound of children by changing the pitch of the sound and increasing the time limit in working on evaluation questions so that the students will be fixed and motivated to immediately complete evaluation questions in this interactive learning media testing to students.

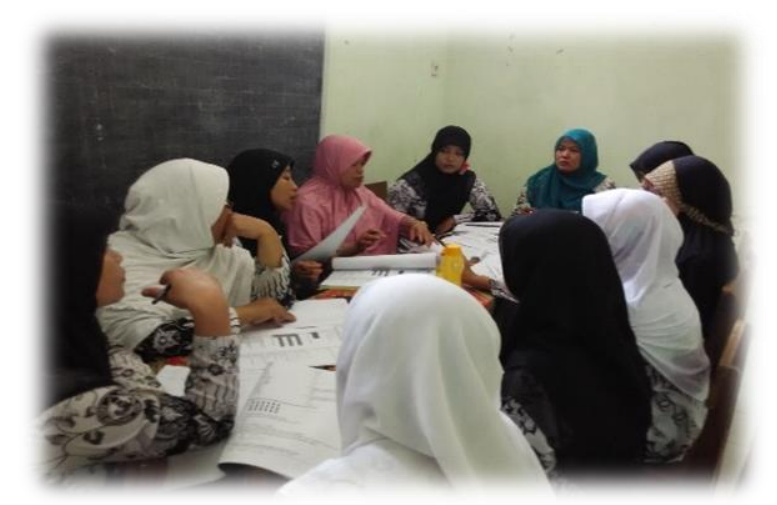

Figure 7. Material and media validation by experts

Results of revisions and validations

From the series of development processes that have undergone revisions from the initial design, voice narration and limitation of time to working on evaluation questions. The initial design of the guiding figure in this 
interactive learning media was to use figures of children transformed into wayang figures according to learning gamelan The next revision is the narrative tone of voice, which originally used the voice of the adult narrative to be transformed into children's voices by using sound pitch changing techniques using audacity software so that it is more heard as the voice of peers who are expected to be more effective in improving children's learning achievement. Next is the revision of the additional time limit of working the evaluative test. It aims to make children more deconcentrated and trigger to immediately solve the problem because of time constraints in evaluating questions. Meanwhile, the validation results from four-scale Likert technique questionnaire instruments are analyzed as stated in Table 2 .

Table 2. Scores of Effectiveness Aspect

\begin{tabular}{|c|c|c|c|c|c|c|c|c|c|c|c|c|}
\hline \multirow{2}{*}{ No } & \multirow{2}{*}{ Name } & \multicolumn{10}{|c|}{ Statement No } & \multirow{2}{*}{ Total } \\
\hline & & 1 & 2 & 3 & 4 & 5 & 6 & 7 & 8 & 9 & 10 & \\
\hline 1 & $\mathrm{TH}$ & 3 & 3 & 2 & 3 & 3 & 3 & 3 & 3 & 3 & 3 & 29 \\
\hline 2 & PK & 4 & 4 & 3 & 3 & 3 & 3 & 3 & 3 & 3 & 3 & 32 \\
\hline 3 & SW & 4 & 4 & 3 & 4 & 4 & 4 & 4 & 4 & 4 & 4 & 39 \\
\hline 4 & $\mathrm{AA}$ & 3 & 3 & 3 & 4 & 4 & 3 & 4 & 4 & 3 & 3 & 34 \\
\hline 5 & $\mathrm{Mq}$ & 4 & 3 & 3 & 4 & 4 & 3 & 4 & 4 & 4 & 3 & 36 \\
\hline 6 & $\mathrm{Mt}$ & 4 & 4 & 3 & 4 & 4 & 3 & 4 & 4 & 4 & 4 & 38 \\
\hline 7 & SK & 3 & 4 & 4 & 4 & 3 & 3 & 3 & 4 & 3 & 3 & 34 \\
\hline 8 & SKh & 3 & 4 & 3 & 3 & 4 & 3 & 4 & 3 & 3 & 4 & 34 \\
\hline 9 & RAS & 4 & 4 & 3 & 4 & 3 & 4 & 4 & 4 & 4 & 3 & 37 \\
\hline 10 & SNH & 4 & 4 & 3 & 4 & 4 & 3 & 4 & 4 & 4 & 4 & 38 \\
\hline & Total & 36 & 37 & 30 & 37 & 36 & 32 & 37 & 37 & 35 & 34 & 351 \\
\hline & Average & 3,6 & 3,7 & 3,0 & 3,7 & 3,6 & 3,2 & 3,7 & 3,7 & 3,5 & 3,4 & 3,51 \\
\hline & Percentage (\%) & 90 & 93 & 75 & 93 & 90 & 80 & 93 & 93 & 88 & 85 & 87,8 \\
\hline
\end{tabular}

From the technique, the ideal number that can be obtained is 400 or $100 \%$ while the minimum value is 100 or $20 \%$. 
The classification of assessment results is shown in Table 3. From the classification, it can be concluded that the results of the evaluation from the validation team reach an average final score of 3.51 (or $87.8 \%$ ) in which it belongs to a very good category.

Table 3. Classification of Assessment Results

\begin{tabular}{cc}
\hline Percentage $(\mathrm{P})$ & Category \\
\hline $80 \% \leq \mathrm{P} \leq 100 \%$ & Very good \\
$60 \% \leq \mathrm{P}<80 \%$ & Good \\
$40 \% \leq \mathrm{P}<60 \%$ & Fair \\
$20 \% \leq \mathrm{P}<40 \%$ & Not Good \\
\hline
\end{tabular}

\section{Practical Applications in Learning}

The development of Virtual Javanese Gamelan in broad outline is at the stage of information delivery, and in more detail the process of implementing learning includes several learning activities namely: initial learning activities, core learning activities, and final learning activities.

Planning

Before implementing the scientific approach with the Virtual Javanese Gamelan media, planning is carried out to prepare:

- Javanese Language Syllabus for Class II semester 1 of 2017/2018, with basic competencies (KD) recognizing and describing gamelan instruments.

- Lesson Plan (RPP) stating indicators, mentioning gamelan musical instruments and describing the gamelan instruments.

- Observation sheet of student learning activities.

- Competency test instruments 
Initial activities

Early learning activities include all activities of students from beginning when they enter the room and prepare completeness in learning. The key procedures are:

- Students practice brain gym to balance the development of the right and left brain.

- The teacher provides the motivation for the primacy of learning gamelan.

- Students know the learning objectives.

- The teacher divides the group of students into 9 groups with each group consisting of 2 members.

- The teacher gives an explanation to students on how to use Virtual Javenese Gamelan media to be used, by directing students to first review the competencies about gamelan, then directing students to do group exercises using Virtual Javenese Gamelan media.

- The teacher explains what activities should be carried out by each group (summarizing the material to be presented)

- Students are given the opportunity to practice using a mouse or touchpad.

Core activities

At the core activity conducted by the teacher is to provide group guidance. In this phase, the key procedures are:

- Observe. Students observe a fact related to gamelan material 
contained in the Virtual Javenese Gamelan media

- Ask. Virtual Media Javenese Gamelan gives questions as an effort to guide students to find the connection between facts observed with gamelan material.

- Reasoning. Students do a logical and systematic process of thinking about the facts observed in the gamelan material to be able to answer questions about the Virtual Javanese Gamelan media.

- Try. Students try to solve a number of examples of problems found in the Virtual Javanese Gamelan media related to the gamelan material.

- Conclude. Students make inferences to find and draw conclusions about gamelan.

- Communicate. Students present their observations and summaries in front of the class.

Final activities

In these activities, the teacher gives questions and at the same time gives reinforcement to the material through the use of Virtual Javanese Gamelan media. At the end of the activity students work on tests to measure student learning achievement. The data of test score before and after using virtual media of Javanese gamelan can be seen from Table 4 . 
Table 4. Daily Examination Data Before and After Innovation

\begin{tabular}{|c|c|c|c|c|c|}
\hline \multicolumn{2}{|c|}{$\begin{array}{l}\text { Subject } \\
\text { Grade/Smester } \\
\text { Theme } \\
\text { Passing Grade }\end{array}$} & $\begin{array}{l}: \text { Javanese I } \\
: \text { II/I } \\
: \text { Recognizi } \\
: 70\end{array}$ & $\begin{array}{l}\text { guage } \\
\text { and Describi }\end{array}$ & Gamel & Musical Instruments \\
\hline \multirow[t]{2}{*}{ No } & \multirow[t]{2}{*}{ Name } & \multicolumn{2}{|c|}{$\begin{array}{c}\text { Without Virtual } \\
\text { Javanese Gamelan }\end{array}$} & \multicolumn{2}{|c|}{$\begin{array}{c}\text { With Virtual } \\
\text { Javanese Gamelan }\end{array}$} \\
\hline & & Score & Completion & Score & Completion \\
\hline 1 & $\mathrm{AFH}$ & 80 & Pass & 100 & Pass \\
\hline 2 & AS & 65 & Fail & 82.5 & Pass \\
\hline 3 & EA & 60 & Fail & 87.5 & Pass \\
\hline 4 & $\mathrm{FZ}$ & 67.5 & Fail & 85 & Pass \\
\hline 5 & MMI & 67.5 & Fail & 92.5 & Pass \\
\hline 6 & MM & 45 & Fail & 80 & Pass \\
\hline 7 & MP & 57.5 & Fail & 87.5 & Pass \\
\hline 8 & M & 67.5 & Fail & 90 & Pass \\
\hline 9 & NHF & 80 & Pass & 100 & Pass \\
\hline 10 & $\mathrm{RF}$ & 65 & Fail & 87.5 & Pass \\
\hline 11 & FAR & 77.5 & Pass & 97.5 & Pass \\
\hline 12 & RAP & 72.5 & Pass & 95 & Pass \\
\hline 13 & $\mathrm{RF}$ & 67.5 & Fail & 90 & Pass \\
\hline 14 & RA & 65 & Fail & 82.5 & Pass \\
\hline 15 & SIM & 65 & Fail & 95 & Pass \\
\hline 16 & SA & 75 & Pass & 100 & Pass \\
\hline 17 & TT & 67.5 & Fail & 87.5 & Pass \\
\hline 18 & WNF & 50 & Fail & 80 & Pass \\
\hline
\end{tabular}

\section{Analysis of Learning Innovation Results}

An analysis of the improvement in gamelan learning achievement is shown in Table 5.

Table 5. Analysis of learning data with and without VJG

\begin{tabular}{clcc}
\hline No & Category & $\begin{array}{c}\text { without Virtual Javanese } \\
\text { Gamelan (VJG) }\end{array}$ & $\begin{array}{c}\text { withVirtual Javanese } \\
\text { Gamelan (VJG) }\end{array}$ \\
\hline 1 & Completeness & $27,8 \%$ & $100 \%$ \\
2 & Highest & 80.0 & 100.0 \\
3 & Lowest & 45.0 & 80.0 \\
4 & Average & 66.0 & 90.0 \\
5 & Range & 35.0 & 20.0 \\
\hline
\end{tabular}


Table 5 shows that in the initial conditions there are $27.8 \%$ in the class that have passed their studies, while those of $72.8 \%$ (12 students) have not succeeded in achieving the specified minimum value. So that students can complete learning gamelan, there is a need for learning innovation so that a virtual mutimedia of Javanese gamelan is made. The results obtained after using the virtual multimedia of Javanese gamelan reach $100 \%$ completion. This shows the increase in learning achievement by $72.8 \%$.

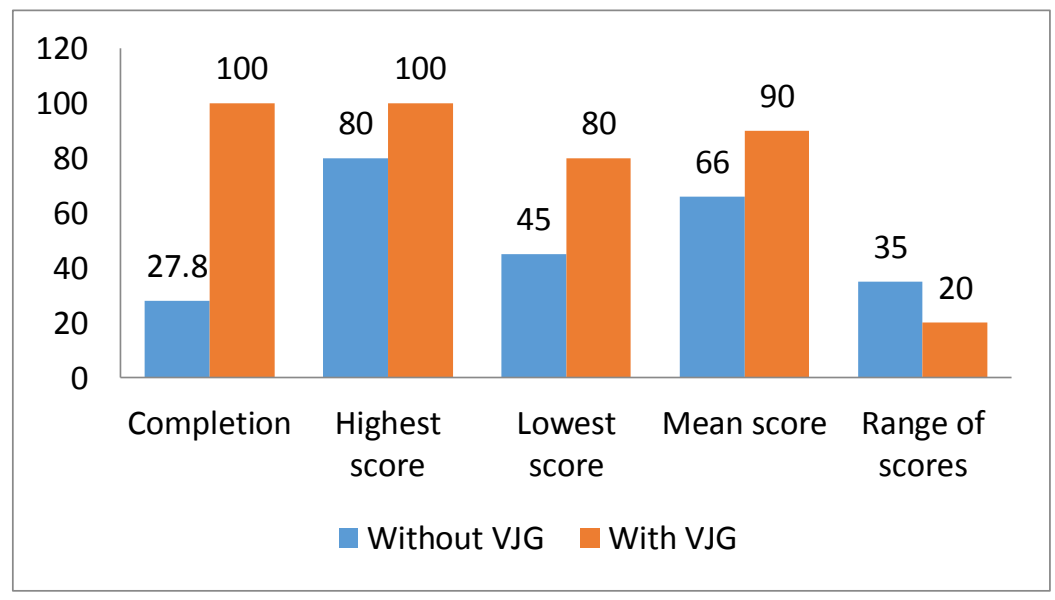

The chart of learning achievement before $\&$ after using VJG

Besides, there is an increase in the lowest value from the initial condition of 45 to 80 at the time of using the media, which means an increase of 35 points. The highest value from the initial condition of 80 to 100 is a 15 point increase. The average value of 66 in the initial conditions becomes 90 after using media, which means 24 point increase. From these data it can be concluded that virtual Javanese gamelan can improve the results of gamelan learning of second garaders of MI Miftahul Huda 01. So this is 
in accordance with the theory which says that interactive learning media can improve student learning achievement.

\section{CONCLUSION}

The conclusions that can be formulated in this report are that this research has succeeded in developing an interactive Virtual Javanese Gamelan learning media as an effective learning media for gamelan material with the reseach and development method because it has been tested both in terms of material and aspects of learning media. Meanwhile, the second point is that Virtual Interactive Learning Media Javanese Gamelan can improve the learning achievement of gamelan of the second graders at MI Miftahul Huda 01.

\section{REFERENCES}

Arsyad, A. (2011). Media Pembelajaran. Jakarta: Rajagrafindo Persada

Asyhar, R. (2011). Kreatif Mengembangkan Media Pembelajaran. Jakarta: Gaung Persada (GP) Press Jakarta.

Baharudin, (2007). Teori Belajar \&Pembelajaran. Yogyakarta: Ar-Ruzz Media

Ferdiansyah, F. (2010). Kesenian Karawitan - Gamelan Jawa. Yogyakarta: Garailmu.

Munadi,Y. (2008). Media Pembelajaran:Suatu Pendekan Baru. Jakarta: Gaung Persada Press

Sudjana, N. (2009). Penilain Hasil Proses Belajar Mengajar, Bandung: Remaja Rosdakarya 
Mudarrisa: Jurnal Kajian Pendidikan Islam, Vol. 10, No. 2, 2018

Sukiman. (2012).Pengembangan Media Pembelajaran.Yogyakarta: Pustaka Insan Madani

Suprijono, A. (2009). Cooperativ Learning. Yogyakarta: Pustaka Pelajar. 